https://nv.nltu.edu.ua

\title{
СТАН ПЕНСІЙНОГО ЗАБЕЗПЕЧЕННЯ ВІЙСЬКОВОСЛУЖБОВЦІВ І ЧЛЕНІВ ЇХНІХ СІМЕЙ
}

Проаналізовано стан пенсійного забезпечення військовослужбовців і членів їх сімей та осіб, звільнених з військової служби, в Україні та можливості адаптації зарубіжного досвіду до вітчизняних умов. Тема реформування пенсійної системи України є однією з найболючіших та найактуальніших тем останніх десятиліть. Відновлення справедливості у визначенні пенсійних виплат $є$ основною метою всіх кроків пенсійної реформи. Водночас, пенсійне забезпечення є однією 3 найбільших проблем державної політики XXI ст. не тільки в Україні. Саме тому аналіз набутого досвіду реформ інших країн може дати змогу уникнути багатьох проблемних моментів реформування та допомогти виокремити основні найефективніші кроки процесу трансформації пенсійної системи України. Предметом цього дослідження $\epsilon$ пенсійне забезпечення військовослужбовців. Адже останні роки затяжного збройного конфлікту на Сході України актуалізували питання соціальної захищеності саме категорії військовослужбовців і членів їхніх сімей. Вирішення цих питань пришвидшить темп становлення стандартів соціального захисту військових Збройних Сил України. Розглянуто соціальний захист військовослужбовців як діяльність держави у сфері соціальної політики, яка спрямована на забезпечення гідного рівня життя для військовослужбовців та членів їхніх сімей. Описано багаторівневу ієрархію системи соціального захисту військовослужбовців Збройних Сил України. Проаналізовано функції Міністерств та інституцій, які забезпечують функціонування системи соціального захисту військовослужбовців загалом. Здійснено аналіз видів пенсійного забезпечення, на які мають право особи, звільнен і 3 військової служби в нашій країні. Розмір пенсійних виплат та інших видів грошового забезпечення є базою для нарахування пенсій військовослужбовцям нашої держави. Актуальним завданням реалізації пенсійної реформи є уникнення "зрівнялівки" у розмірах пенсій різних категорій населення. У разі нарахування пенсій військовослужбовцям перерахунок пенсій здійснюють 3 порушеннями, зокрема ігноруючи певні складові грошового забезпечення, а саме: оплату за науковий ступінь, оплату за вчене звання та низку надбавок, серед яких надбавки за спортивні звання, за почесні звання та за виконання певних спеціальних функцій у межах службових повноважень. Одним із кроків поліпшення ефективності механізму соціального захисту $\epsilon$ вивчення, аналіз та переймання досвіду аналогічної роботи закордонних інституцій. Для визначення шляхів реформування пенсійного забезпечення військовослужбовців здійснено порівняння аналогічного досвіду пенсійного забезпечення військовослужбовців і членів їхніх сімей на приклад і провідних країн - членів НАТО (США, Великобританії, Франції). Вибір цих країн зумовлений тим, що реформування вітчизняної системи пенсійного забезпечення військовослужбовців у пострадянській Україні багато в чому грунтується на запозиченні досвіду названих країн. Зроблені висновки містять рекомендації щодо рефорування системи пенсійного забезпечення військовослужбовців України.

Ключові слова: пенсія; пенсійний вік; пенсійне страхування; пенсійне законодавство; соціальний захист.

\section{Вступ}

Ефективне функціонування воєнної організації нашого суспільства в умовах його трансформації та подальшого розвитку невід'ємно пов'язане із формуванням соціального забезпечення військовослужбовців, а відповідно $є$ наслідком формування позитивного іміджу Збройних Сил та привабливості військової служби. За умов організації науково обгрунтованої, системної та комплексної діяльності, сформований соціальний захист як військовослужбовців, так і членів їхніх сімей значно сприяє зміцненню Збройних Сил, безпеці країни та iï авторитету. Соціальні гарантії несуть не останню аргументацію у виборі військової служби для молоді, а також зумовлюють формування у населення готовності виступити на захист Батьківщини у разі нападу агресора.

Актуальність дослідження. Сьогодні Україна стоїть перед новими викликами, які пов'язані із збройним конфліктом на Сході України, що з кожним роком збільшує кількість військовослужбовців і членів їхніх сімей, а також осіб, звільнених $з$ військової служби, які повинні бути соціально захищені. Визначення дієвої системи фінансування сфери соціального забезпечення цих категорій осіб значно пришвидшує темп становлення стандартів соціального захисту військових Збройних Сил України та відповідного виконання ними завдань,

Інформація про авторів:

Андрейчук Станіслав Казимирович, канд. наук держ. управління, доцент, кафедра соціології та соціальної роботи. Email: a_stanislav@ukr.net; https://orcid.org/0000-0003-3226-7300

Морушко Олександр Олександрович, канд. істор. наук, доцент, кафедра соціальних комунікацій та інформаційної діяльності. Email: morushkoo@gmail.com; https://orcid.org/0000-0001-8872-2830

Гасяк Мар'яна Степанівна, аспірант, кафедра соціології та соціальної роботи. Email: mhasiak@ukr.net; https://orcid.org/0000-0001-9926-2016

Цитування за ДСтУ: Андрейчук С. К., Морушко О. О., Гасяк М. С. Стан пенсійного забезпечення військовослужбовців і членів їхніх сімей. Науковий вісник НлТУ України. 2021, т. 31, № 2. С. 75-80.

Citation APA: Andreychuk, S. K., M. S. Hasiak, \& Moruchko, O. O. (2021). State of pension provision for servicemen and their members of their families. Scientific Bulletin of UNFU, 31(2), 75-80. https://doi.org/10.36930/40310212

Науковий вісник НЛТУ України, 2021, т. 31, № 2

Scientific Bulletin of UNFU, 2021, vol. 31, no 2 
які постали перед українською державою на цьому етапі розвитку країни з урахуванням вимог, що ставляться Європейським Союзом та країнами-членами НАТО.

Об'єкт дослідження - система пенсійного забезпечення.

Предмет дослідження - методики визначення пенсійного забезпечення військовослужбовців,

Мета роботи - визначення шляхів реформування пенсійного забезпечення військовослужбовців, що дасть змогу проаналізувати функції державних інституцій.

Для досягнення зазначеної мети визначено такі основні завдання дослідження: визначити стан та перспективи розвитку пенсійного забезпечення військовослужбовців і осіб звільнених, з військової служби в Україні та світі.

Наукова новизна отриманих результатів дослідження - вперше здійснено огляд пенсійного забезпечення військовослужбовців країн НАТО (США, Великобританії, Франції) й України. Зокрема, здійснено аналіз нормативно-законодавчих актів країн НАТО та України щодо нарахування пенсій для військових і осіб, звільнених 3 військової служби, проаналізовано функції державних інституцій, які здійснюють пенсійне забезпечення названих категорій громадян.

Практична значущість результатів дослідження реформування пенсійного забезпечення військовослужбовців в Україні рухається в правильному напрямку. Проте ще потрібно змінити певні нормативно-законодавчі акти для того, щоб врахувати деякі надбавки і доплати, які сьогодні в чинному законодавстві не беруть до уваги, а звідси низькі пенсії військовослужбовців і осіб, звільнених з військової служби. Також використати досвід пенсійної системи військових в США для впровадження державної накопичувальної системи або особистого пенсійного рахунку для підвищення розміру пенсій військовослужбовцям.

Аналіз останніх досліджень та публікацій. Соціальний захист військовослужбовців i, зокрема, їх пенсійне забезпечення $є$ одним із заходів соціального забезпечення громадян загалом і тому є предметом дослідження, що цікавить низку вітчизняних і зарубіжних вчених і практиків. Зокрема такі науковці, як В. Алещенко [1], В. Довгаль [4], В. Мунтіян [10], В. Кириленко [7], С. Ветлинський [20], Л. Цюкало [13], А. Лопата [8], А. Папікян [11] розглядали питання соціального захисту військовослужбовців, специфіку соціального забезпечення та нормативно-правове забезпечення державних гарантій соціального захисту військовослужбовців. Проте варто зазначити, що на сьогодні не всі аспекти пенсійного забезпечення колишніх військових достатньо вивчені та отримали належне наукове обгрунтування.

Матеріали та методи дослідження. У цій роботі використано порівняльно-типологічний метод дослідження, що дав змогу порівняти нормативно-законодавчу базу, яка забезпечує функціонування пенсійного забезпечення військовослужбовців України та країн НАТО (США, Великобританії, Франції). А також аналіз та синтез, що базується на деяких теоретичних міркуваннях причинно-наслідкового зв'язку явищ, які, на наш погляд, $€$ істотними у нашому дослідженні, а саме подібність функціонування пенсійного забезпечення військовослужбовців країн НАТО та України, і відмінність у нарахуванні пенсій військовослужбовцям і особам, звільненим з військової служби, названих вище країн.

\section{Результати дослідження та їх обговорення}

Поняття "соціальний захист" та "соціальне забезпечення" більшість науковців пояснюють як тотожні та взаємозамінні посилаючись на зміни, як і відбулися в законодавстві України.

Насамперед варто визначити, що саме означає поняття соціального захисту загалом і як цей термін пояснюють у контексті військової служби. Н. Болотіна у своїй науковій роботі визначає соціальний захист як систему юридичних, економічних, фінансових та організаційних заходів і засобів держави, які спрямовані на зменшення або уникнення впливу несприятливих соціальних ризиків на всі категорії населення [2].

Під соціальним захистом військовослужбовців потрібно розглядати діяльність держави у сфері соціальної політики, яка спрямована на забезпечення гідного рівня життя для військовослужбовців і членів їхніх сімей. Сюди також входять підтримка та відновлення їхнього морального та фізичного стану.

Ветлинський С. у своїй роботі [20] зробив вдалий наголос на тому, що сучасне забезпечення соціального захисту військовослужбовців - це цілеспрямована система діяльності держави і громадянського суспільства щодо забезпечення дієвості нормативно-правових актів, якими встановлені відповідні пільги, гарантії та компенсації військовослужбовцям у зв'язку з виконанням ними обов'язків військової служби.

Одним із важливих кроків держави у сфері соціальної політики є запровадження комплексу державних соціальних і правових гарантій для захисту військовослужбовців і членів їхніх сімей, цей обов'язок держави прописано у Законі України "Про статус ветеранів війни, гарантії їх соціального захисту" [22] та у Законі України "Про соціальний і правовий захист військовослужбовців та членів їх сімей" [21]. Також не менш важливим $є$ те, що наша держава переймає досвід своїх закордонних колег, чим поліпшує ефективність механізму соціального захисту.

Соціальний захист військовослужбовців Збройних Сил України є системою, тому що його можна розділити на взаємопов'язані й взаємодіючі частини і компоненти. Ці компоненти мають власну структуру й тому можуть бути визначені як підсистеми вихідної, більшого рівня системи. Відокремлені у такий спосіб підсистеми можна поділити на взаємозв'язані підсистеми другого й наступного рівнів. При цьому кожна система має регулюватися. Процес регулювання багаторівневої ієрархії будь-якої системи, забезпечення зв'язку між ії різними рівнями виступає як процес управління системою, як різноманітні за жорсткістю й формами способи зв'язку рівнів, що забезпечують нормальне функціонування і розвиток у складних системах [7].

Систему соціального захисту військовослужбовців в Україні доцільно вдосконалювати на підставі таких принципів [6]:

- поєднання особистих інтересів військовослужбовців з інтересами держави при взаємній відповідальності;

- співвідношення необхідного рівня соціальної захищеності 3 реальними можливостями іiї забезпечення;

- забезпечення соціального захисту військовослужбовців на компенсаційній основі з безумовним виконанням ними своїх обов'язків та добровільним прийняттям певних обмежень своїх прав;

- створення законних (легітимних) механізмів і форм реалізації державної соціальної політики у військовій сфері; 
- обов'язкового включення до сфери дії норм соціального захисту членів сімей військовослужбовців, ветеранів війни, військової служби, учасників бойових дій та інвалідів війни;

- створення найсприятливіших умов для роботи державних органів щодо забезпечення соціальних прав військовослужбовців і членів їхніх сімей.

На сьогодні система соціального захисту військовослужбовців містить встановлені законом права і свободи, гарантії, пільги та компенсації, які надаються військовослужбовцям у зв'язку 3 виконанням ними обов'язків військової служби.

Якщо йдеться про систему соціального захисту військовослужбовців загалом, то це поняття потрібно розглядати як сукупність функцій Міністерства оборони (здійснює заходи, спрямовані на реалізацію соціальноекономічних і правових гарантій військовослужбовцям, членам їхніх сімей та працівникам Збройних Сил України, бере участь у формуванні та реалізації державної політики з питань національної безпеки у воєнній сфеpi, оборони i військового будівництва, підготовці проєктів законодавчих та інших нормативних актів у сфері оборони, забезпечує їх виконання у Збройних Силах України), Міністерства соціальної політики (є головним органом у системі центральних органів виконавчої влади 3 формування та забезпечення реалізації державної політики у сферах: трудових відносин, соціального захисту, соціального обслуговування населення), Міністерства у справах ветеранів війни (соціальний захист ветеранів війни та учасників антитерористичної операції, зокрема, щодо забезпечення їх психологічної реабілітації, санаторно-курортним лікуванням, технічними та іншими засобами реабілітації, житлом, надання освітніх послуг та організації поховання; соціальна та професійна адаптація військовослужбовців, які звільняються, осіб, звільнених 3 військової служби, а також учасників антитерористичної операції; реалізація в межах своїх повноважень державної політики у сфері волонтерської діяльності щодо надання волонтерської допомоги) та Пенсійного фонду (реалізація державної політики 3 питань пенсійного забезпечення та ведення обліку осіб, які підлягають загальнообов'язковому державному соціальному страхуванню; внесення пропозицій Міністрові соціальної політики щодо забезпечення формування державної політики із зазначених питань; виконання інших завдань, визначених законом). Розглядаючи функції, які названі інституції виконують, можна простежити, що вони перетинаються між собою і це дає підстави на трактування поняття "система соціального захисту військовослужбовців"

Щодо закордонного досвіду пенсійного забезпечення військовослужбовців і членів їхніх сімей, а також осіб, звільнених з військової служби, варто зазначити, що у кожної країни є свій підхід до соціального захисту цієї категорії осіб. Багато іноземних держав практикують соціальний захист, який фінансується за рахунок коштів державного бюджету (пільги, соціальні програми, реабілітація). Також важливу роль відіграє страхування військовослужбовців, яке діє у разі настання хвороби, травми, або загибелі (виплачується сім'ям військовослужбовців), воно має обов'язковий характер та забезпечує повне покриття витрат на лікування.

Зарубіжний досвід пенсійного забезпечення військовослужбовців, на наш погляд, варто аналізувати на прикладі провідних країн - членів НАТО (США, Великобританії, Франції). Вибір цих країн зумовлений тим, що реформування вітчизняної системи пенсійного забезпечення військовослужбовців у пострадянській Україні багато в чому грунтується на запозиченні досвіду названих країн.

У Сполучених Штатах Америки діє найефективніша система соціальної допомоги військовослужбовцям i членам їхніх сімей, а також особам, звільнених з військової служби. У США Міністерство оборони цієї країни приділяє велику увагу забезпеченню своїх військовослужбовців, ветеранів військової служби різними пільгами і привілеями, розцінюючи це як найважливішу їх соціальну гарантію, оскільки цей чинник безпосередньо впливає на бажання американців служити в національних Збройних Силах і сприяє збереженню в них висококваліфікованих фахівців. Сфера соціального захисту військовослужбовців, ветеранів військової служби у Сполучених Штатах керується всього трьома нормативно-правовими актами. Вони регулюють сферу охорони здоров'я ветеранів (реабілітація інвалідів), забезпечення житлом, працевлаштування та сприяння адаптації ветеранів після завершення військової служби [5].

Під соціально значущими пільгами i привілеями військовослужбовців Збройних Сил США розуміють певні переваги, що надаються громадянам цієї країни у зв'язку з несенням ними військової служби, а також з іiі закінченням або виконанням інших військових обов'язків. Вони призначаються залежно від заслуг військовослужбовців, конкретних умов несення ними військової служби і містять такі складові: пенсійне забезпечення осіб, звільнених в запас або відставку за віком і вислугою років; пенсії ветеранам військової служби за інвалідністю, отриманої внаслідок їі проходження; надання допомоги в отриманні громадянської освіти самими військовослужбовцями, а також членами їхніх сімей; надання страхових позичок на будівництво житла або його ремонт; страхування життя; медичне забезпечення військовослужбовців і членів їхніх сімей; психотерапевтична допомога; надання допомоги у працевлаштуванні на "громадянці"; виплати допомоги 3 безробіття після звільнення 3 військової служби; здійснення професійної реабілітації. Для кожних пільги і привілею розроблено програму з їі забезпечення і резервуються значні за обсягом фінансові ресурси, які закладаються в Федеральний бюджет [10].

Такий широкий перелік послуг досягається тим, що Міністерство у справах ветеранів діє спільно з іншими Міністерствами США, а саме: Міністерством охорони здоров'я, Міністерством національної безпеки та Міністерством оборони. Великим плюсом системи соціального захисту військовослужбовців Сполучених Штатів $\epsilon$ програми страхування. Ці програми гарантують безкоштовне довічне медичне страхування, яке повністю покриває всі потреби військовослужбовців. Цей вид страхування фінансується коштами бюджету. У разі смерті військовослужбовця внаслідок виконання військового завдання, його родина отримає компенсацію у розмірі 400 тис. доларів. Варто зазначити, що створене Міністерство у справах ветеранів в Україні є дещо подібним як за структурою, так і за деякими функціями до Міністерства у справах ветеранів США.

У Великій Британії влада цієї країни вживає необхідних заходів для того, що б комфортні побутові умови, порівняно високий рівень грошового утримання, зокрема заохочувальні виплати, компенсації, різна до- 
помога і пенсійне забезпечення сприяли неухильному залученню на військову службу добровольців-контрактників. Ось, власне, чому і рівень пенсійного забезпечення військовослужбовців у Великобританії, і рівень їх грошового утримання $\epsilon$ одними 3 найвищих порівняно 3 їх аналогами в інших країнах-членах НАТО [10].

Елементами військово-соціального законодавства Великобританії є, зокрема, Закони "Про армії" 1975 р., "Про резерви" 1996 р., Інструкція Міноборони "Терміни та умови проходження військової служби" 1996 р. Грошове утримання особового складу ЗС цієї країни визначається залежно від військового звання і вислуги років, яка для військовослужбовців у військовому званні "майор" - "полковник" становить 8 років, "капітан" 6 років, "лейтенант" - 4 роки, "штабс-сержант - ворентофіцер" - 18 років. Грошове утримання містить основний оклад плюс численні надбавки (за проходження служби на заморських територіях, у Північній Ірландії; екіпажам кораблів і суден ВMC, що перебувають у плаванні; на розквартирування, зокрема і зі сім'єю; на оплату гаража і парковки; витрати на комунальні послуги та ін.). Норма військової пенсії (річна) визначається у твердій грошовій сумі з урахуванням військового звання і вислуги років (мінімум - 16 років). Її розмір збільшується за кожен рік понад обов'язковий термін військової служби.

За загальним правилом, у разі виходу військовослужбовця на пенсію у зв'язку із закінченням відповідного строку військової служби, йому виплачується одноразова допомога в розмірі 3-річного пенсійного забезпечення. Окрім цього, військовий Збройних Сил Великобританії, який звільняється в запас або відставку, має право отримати частину свого пенсійного забезпечення за кілька років наперед. У разі дотермінового розірвання контракту не за ініціативою військовослужбовця (у зв'язку зі скороченням штатів) йому виплачується до 18 місячних окладів грошового утримання відповідно до останньої штатної посади на військовій службі.

У Міністерстві оборони Великобританії немає підрозділу, що займається професійною перепідготовкою військовослужбовців, звільнених у запас або відставку. Для цієї мети призначена Державна система перепідготовки кадрів, що входить до Міністерства освіти.

Військовослужбовці Збройних Сил Великобританії у разі виходу на пенсію після закінчення повного терміну служби та їхні дружини (чоловіки) мають право на безкоштовне медичне обслуговування, безкоштовне (для інвалідів та учасників бойових дій) або частково оплачуване (для окремих категорій) забезпечення медикаментами та санаторно-курортне лікування [3].

Щодо військовослужбовців Франції, то їх звільнення зі Збройних Сил Французької Республіки здійснюється на підставі вимог військово-соціального законодавства цієї країни і конкретного акту правозастосування - урядового декрету. Військовослужбовець Збройних Сил Франції може бути звільнений в запас (відставку) за віком, за вислугу років, за особистим проханням за наявності права на пенсію, за станом здоров'я, за вчинення дисциплінарних проступків, у зв'язку з безперспективністю місця служби (останнє дозволяє йому отримати військове звання на ступінь вище по займаній штатній посаді на військовій службі). Особи, звільнені в запас або відставку за особистим проханням, залежно від вислуги років, отримують військову пенсію негайно або після досягнення граничного віку у відповідному військовому званні.

Для військовослужбовців встановлено два види пенсій: 1) за вислугою років; 2) з інвалідності. Члени сім'ї військовослужбовця мають право на пенсію в разі втрати годувальника. Право на отримання пенсії за вислугу років мають особи, які прослужили у збройних силах Франції не менше 15 років. Розміри цієї військової пенсії коливаються в межах 60-80 \% від основного окладу грошового утримання.

У сфері пенсійного забезпечення військовослужбовців проглядається тверда позиція держави: військові пенсії не можуть бути скорочені до розміру трудових пенсій з старості, інших пенсій, що виплачуються громадянам країни на загальних підставах ("Біла книга 3 оборони і національної безпеки" - офіційна військова доктрина Франції). Однак, як свідчать французькі експерти, військова пенсія, пропорційна вислузі років, багатьом військовим пенсіонерам не забезпечує сучасний прожитковий мінімум [12].

Повертаючись до системи соціального захисту військовослужбовців та членів їхніх сімей та осіб звільнених 3 військової служби в Україні загалом, а також аналізуючи стан пенсійного забезпечення військовослужбовців у нашій Державі, варто апелювати до Закону України "Про соціальний і правовий захист військовослужбовців та членів їх сімей", згідно з яким пенсійне забезпечення військовослужбовців після звільнення їх 3 військової служби провадиться відповідно до Закону України "Про пенсійне забезпечення військовослужбовців та осіб начальницького і рядового складу органів внутрішніх справ" [9].

На сьогодні особи, звільнені з військової служби, мають право на такі види пенсійного забезпечення:

- довічну пенсію за вислугу років;

- пенсію з інвалідності;

- пенсію в разі втрати годувальника.

Пенсії за вислугу років виплачується:

- особам офіцерського складу, прапорщикам i мічманам, військовослужбовцям надстрокової служби та військової служби за контрактом, які мають вислугу 20 років і більше: за вислугу 20 років - 50 \%, а звільненим у відставку за віком або за станом здоров'я - 55 \% відповідних сум грошового забезпечення; за кожний рік вислуги понад 20 років 3 \% відповідних сум грошового забезпечення;

- особам офіцерського складу, прапорщикам i мічманам, військовослужбовцям надстрокової служби та військової служби за контрактом, які мають страховий стаж 25 років $і$ більше, 3 яких не менше 12 календарних років і 6 місяців становить військова служба: за страховий стаж 25 років $50 \%$ і за кожний повний рік стажу понад 25 років - $1 \%$ відповідних сум грошового забезпечення;

- особам офіцерського складу, прапорщикам i мічманам, військовослужбовцям надстрокової служби та військової служби за контрактом, які звільняються з військової служби за умов реформування Збройних Сил України: за вислугу 20 років - $50 \%$ відповідних сум грошового забезпечення із збільшенням цього розміру на $3 \%$ за кожний повний рік вислуги понад 20 років, але не більше ніж $65 \%$ відповідних сум грошового забезпечення.

Максимальний розмір пенсії за вислугу років не має перевищувати 70 \% відповідних сум грошового забезпечення, а особам, які під час проходження служби брали участь у ліквідації наслідків аварії на Чорнобильській АЕС і віднесені в установленому законом порядку до категорії $1-100 \%$, до категорії $2-95 \%$ [16]. Зазна- 
чимо, що згідно з чинним законодавством розмір пенсій залежить від розмірів грошового забезпечення. Згідно 3 розділом 3 статті 43 Закону України "Про пенсійне забезпечення осіб, звільнених $з$ військової служби, та деяких інших осіб [14] базою для обчислення пенсії визначається "розмір грошового забезпечення, враховуючи відповідні оклади за посадою, військовим (спеціальним) званням, процентну надбавку за вислугу років, щомісячні додаткові види грошового забезпечення (надбавки, доплати, підвищення) та премії в розмірах, встановлених законодавством.

Згідно з Постановою КМУ № 154 від 02.03.2016 p. Про внесення змін до постанови Кабінету Міністрів України від 17 липня 1992 р., № 393 від 17 липня 1992 р., № 393 "Про порядок обчислення вислуги років, призначення та виплати пенсій і грошової допомоги особам офіцерського складу, прапорщикам, мічманам, військовослужбовцям надстрокової служби та військової служби за контрактом, особам начальницького і рядового складу органів внутрішніх справ, поліцейським та членам їхніх сімей" [18] пенсії обчислюються з розміру грошового забезпечення, з якого було сплачено єдиний внесок на загальнообов'язкове державне соціальне страхування, а до 1 січня 2011 р. - страхові внески на загальнообов'язкове державне пенсійне страхування з урахуванням таких його видів:

- відповідних окладів за посадою, військовим (спеціальним) званням (для осіб рядового і начальницького складу органів і підрозділів цивільного захисту щомісячної надбавки за спеціальне звання) та відсоткової надбавки за вислугу років у розмірах, установлених за останньою штатною посадою, займаною перед звільненням;

- щомісячних додаткових видів грошового забезпечення (надбавки, доплати, підвищення, окрім щомісячних надбавок (доплат), установлених особам, які мають право на пенсію за вислугу років згідно із законодавством і залишені за їх згодою та в інтересах справи на службі) та премії, виходячи 3 розміру щомісячних додаткових видів грошового забезпечення та премії за 24 останні календарні місяці служби підряд перед звільненням [8].

Прикінцевими положеннями Закону України від 3 жовтня 2017 р., № 2449VIII "Про внесення змін до деяких законодавчих актів України щодо підвищення пенсій" Кабінету Міністрів України було доручено до 1 листопада 2017 р. підготувати і подати на розгляд Верховної Ради України законопроект щодо перерахунку пенсій військовослужбовців 3 урахуванням нових розмірів грошового забезпечення [15].

Одним 3 найактуальніших питань, пов'язаних $з$ реалізацією пенсійної реформи та для уникнення "зрівнялівки" у розмірах пенсій різних категорій населення, $є$ забезпечення особливих умов нарахування пенсійного забезпечення військовослужбовців, які впродовж довгих років виконували обов'язки, пов'язані із захистом Батьківщини та не мали іншого джерела доходів, окрім грошового забезпечення. При цьому не обов'язково виносити окремий закон щодо перерахунку розміру пенсій військовим, Уряд повинен виконати чинний, тобто врахувати розміри грошового утримання, встановлені Постановою КМУ №704 "Про грошове забезпечення військовослужбовців, осіб рядового і начальницького складу та деяких інших осіб", яка набувала чинності $з$ 01.01.2018 року [13].

Проте, після Постанови Кабінету Міністрів України № 103 "Про перерахунок пенсій особам, які звільнені 3 військової служби, та деяким іншим категоріям осіб"
[19], середньомісячна пенсія військових зросла. Але положення зазначеної вище Постанови в частині визначення порядку перерахунку та виплати військових пенсій суперечать вимогам закону, а Пенсійний фонд України приступив 31 березня 2018 р. до іiі виконання. Так, пунктом 1 цієї Постанови передбачено, що пенсії, які призначені до 1 березня 2018 р. згідно із Законом України від 09.04.1992 р., № 2262-XII, підлягають перерахунку з урахуванням визначених станом на 1 березня 2018 р. Постановою КМУ від 30.08 .2017 р., № 704 розмірів: окладу за посадою; окладу за військовим званням; відсоткової надбавки за вислугу років за відповідною або аналогічною посадою, яку особа обіймала на дату звільнення зі служби [17]. Із зазначеного вбачається, що Кабінет Міністрів України перерахунок пенсій пов'язує тільки з трьома складовими грошового забезпечення, ігноруючи передбачену Законом решту його складових, а саме:

1) оплату за науковий ступінь доктора філософії (кандидата наук) або доктора наук з відповідної спеціальності, за наявності двох наукових ступенів доплата встановлюється за одним (вищим) науковим ступенем;

2) оплату за вчене звання військовослужбовцям, які займають посади, пов'язані з педагогічною або науковою діяльністю і мають вчене звання доцента (старшого наукового співробітника), та наявності двох або більше вчених звань доплата встановлюється за одним (вищим) званням;

3) надбавку за спортивні звання військовослужбовцям;

4) надбавку за почесні звання України, СРСР, союзних республік СРСР військовослужбовцям, які мають почесні звання "заслужений" або "народний";

5) надбавку за виконання функцій державного експерта 3 питань таємниць та надбавку за службу в умовах режимних обмежень військовослужбовцям.

Відтак розмір щомісячного пенсійного забезпечення військових пенсіонерів істотно занижено [4].

\section{Висновок}

На сьогодні Україна в питанні реформування пенсійного забезпечення військовослужбовців рухається в правильному напрямку, проте, окрім державних пенсій, потрібно ще додати державну накопичувальну систему або особистий пенсійний рахунок, на який військовий щомісячно повинен відраховувати певний відсоток від своєї заробітної плати. Для вирішення цього питання варто запозичити досвід пенсійної системи для військових США. Необхідно також доопрацювати деякі законодавчі акти, за якими здійснюється нарахування пенсій військовослужбовцям. Зокрема, сьогодні при розрахунку пенсії, ми бачимо, що враховується тільки ставка посадового окладу, за вислугу років, надбавка за кваліфікацію та виплата за почесні звання, але не враховується виплата надбавки за особливості проходження служби, виплата доплати за науковий ступінь та за вчене звання, надбавка курсантам і слухачам навчальних закладів, відсотків посадового окладу та низка інших доплат. Власне, ці види надбавок і доплат повинні враховуватись під час нарахування пенсій військовослужбовцям і особам, звільненим з військової служби.

\section{References}

1. Aleshchenko, V. (2020). Systema vnutrishno komunikatsiinoi roboty: suchasnyi stan ta shliakhy podalshoho rozvytku. Nauka $i$ oborona, 4, 46-52. [In Ukrainian]. 
2. Bolotina, N. (2010). Pravo liudyny na sotsialnyi zakhyst. Kyiv: Znannia. Seriia "Yurydychna". [In Ukrainian].

3. Brovkin, V. (1993). Komplektovanie Vooruzhennykh Sil Velikobritanii. Zarubezhnoe voennoe obozrenie. Retrieved from: https://target.ucoz.ru/publ/24-1-0-398. [In Russian].

4. Dovhal, V. (2018). Spetsyfika sotsialnoho zabezpechennia viiskovosluzhbovtsiv. Ternopil: TNEU. [In Ukrainian]. [In Ukrainian].

5. Korolov, S. (2006). Sotsialnyi zakhyst viiskovosluzhbovtsiv Zbroinykh Syl Ukrainy: istorychnyi aspekt. Candidate Dissertation for Historical Sciences. Natsionalna Akademiia Obrony Ukrainy, Kyiv. [In Ukrainian].

6. Korolov, S. (2010). Normatyvno-pravove zabezpechennia derzhavnykh harantii sotsialnoho zakhystu viiskovosluzhbovtsiv v period reformuvannia Zbroinykh Syl Ukrainy: istorychnyi aspekt. Kharkiv. Kharkivskyi universytetu Povitrianykh Syl, 4(26), 264 268. Retrieved from: nbuv.gov.ua.j-pdf.ZKhUPS_2010_4_60. [In Ukrainian].

7. Kyrylenko, V. (2016). Sotsialnyi zakhyst viiskovosluzhbovtsiv yak zasib zapobihannia konfliktu mizh armiieiu i suspilstvom. Konflikty v suspilstvi: diahnostyka i profilaktyka. Chernivtsi: Chernivetskyi natsionalnyi universytet imeni Yuriia Fedkovycha, 308-313. [In Ukrainian]. [In Ukrainian].

8. Lopata, A. (2018). Yakoiu maie buty pensiia u viiskovykh? Taiemni plany uriadovykh reformatoriv. Retrieved from; https://veteranychernobyl.info/yakoyu-maye-buti-pensiya-uvijskovix-tayemni-plani-uryadovix-reformatoriv. [In Ukrainian].

9. Medvedchuk, O. (2009). Reformuvannia systemy pensiinoho zabezpechennia v Ukraini. Ekonomika ta derzhava. 3, 58-60. Retrieved from: http://nbuv.gov.ua/UJRN/ecde 20093 17. [In Ukrainian].

10. Muntiian, V. (2012). Ekonomika i oboronni vytraty. Analiz zarubizhnykh doslidzhen $i$ ukrainskyi shliakh rozvytku. Kyiv: NDFI. [In Ukrainian].

11. Papikiian, A. (2014). Derzhava i sotsialnyi zakhyst viiskovosluzhbovtsiv: prava i harantii. Naukovyi visnyk Lvivskoho derzhavnoho universytetu vnutrishnikh sprav. [In Ukrainian].

12. Terekhov, V. (1999). Konversiia voennosluzhashhikh vo Frantcii. Zarubezhnoe voennoe obozrenie. Retrieved from: https://target.ucoz.ru/publ/24-1-0-398. [In Russian].
13. Tsiukalo, L. (2017). Sotsialne zabezpechennia viiskovosluzhbovtsiv zbroinykh syl Ukrainy ta yoho sut. Naukove vydannia Ukrainy z pytan ekonomiky. Dnipro. Vydavnytstvo Dniprovskoho derzhavnoho ahrarno-ekonomichnoho universytetu. Retrieved from: http://www.economy.in.ua/pdf/1 2018/28.pdf. [In Ukrainian].

14. Ukraina. "Zakon Pro pensiine zabezpechennia osib, zvilnenykh z viiskovoi sluzhby, ta deiakykh inshykh osib. "№ 2262-XII. (09.04.1992). Retrieved from: https://zakon.rada.gov.ua/laws/show/2262-12. [In Ukrainian].

15. Ukraina. "Zakon Pro vnesennia zmin do deiakykh zakonodavchykh akti v Ukrainy shcho do pidvyshchennia pensii. "№ 2449-VIII (2017). Retrieved from: https://zakon.rada.gov.ua/laws/show/2148-19. [In Ukrainian].

16. Ukraina. "Zakon Pro zahalnooboviazkove derzhavne pensiine strakhuvannia" № 1058-IV. (09.07.2003). Retrieved from; https:// zakon.rada.gov.ua/laws/show/1058-15. [In Ukrainian].

17. Ukraina. Postanova Kabinetu Ministriv "Pro hroshove zabezpechennia viiskovosluzhbovtsiv, osi b riadovoho i nachalnytskoho sklad u ta deiakykh inshykh osib" № 704. (2017). Retrieved from; https://zakon.rada.gov.ua/laws/show/704-2017. [In Ukrainian].

18. Ukraina. Postanova Kabinetu Ministriv "Pro vnesennia zmin do postanovy Kabinetu Ministriv Ukrainy" № 393. (1992). Retrieved from: https:/zakon.rada.gov.ua/laws/show/154-2016-p. [In Ukrainian].

19. Ukraina. Postanova Kabinetu Ministriv № 103. (2018). Pro pererakhunok pensi ${ }_{\text {y }}$ osobam, yak i zvilnen i z viiskovoi sluzhby, $t$ a deiakym inshym katehoriiam osib. Retrieved from: https://zakon.rada.gov.ua/laws/show/103-2018. [In Ukrainian].

20. Vetlynskyi, S. (2016). Sotsialnyi zakhyst viiskovosluzhbovtsiv v umovakh provedennia antyterorystychnoi operatsii. Efektyvnist derzhavnoho upravlinnia, 4(1), 198-205. [In Ukrainian].

21. Zakon Ukrainy "Pro sotsialnyi i pravovyi zakhyst viiskovosluzhbovtsiv ta chleniv yikh simei" № 2011-XII. (20.12.1991). Retrieved from: https://zakon.rada.gov.ua/laws/show/201112/ed20120812. [In Ukrainian].

22. Zakon Ukrainy "Pro status veteraniv viiny, harantii yikh sotsialnoho zakhystu". № 3551-XII. (22.10.1993). Retrieved from: https://zakon.rada.gov.ua/laws/show/3551-12. [In Ukrainian].

S. K. Andreychuk, O. O. Moruchko, M. S. Hasiak Lviv Polytechnic National University, Lviv, Ukraine

STATE OF PENSION PROVISION FOR SERVICEMEN AND THEIR MEMBERS OF THEIR FAMILIES

The analysis of the state of pension provision was carried out for servicemen, their family members and persons discharged from military service in Ukraine, and the possibility of adapting foreign experience to domestic conditions. The reforming of the pension system of Ukraine is one of the most problematic and relevant issues in recent decades. Restoration of justice in the calculation of pension benefits is the main goal of all stages of pension reform. At the same time, the provision of pensions is one of the biggest problems of the public policy in the 21 century, not only in Ukraine. Therefore, the analysis of the accumulated experiences of reforms in other countries can both provide an opportunity to avoid many problematic aspects of the reform process, and help identify the most effective steps towards the transformation of the pension system in Ukraine. Therefore, pension provision of servicemen is the subject of the article. This is strongly influenced by the reality of a protracted armed conflict in the East of Ukraine which has exacerbated the issue of social security for servicemen and their families. Addressing these issues significantly accelerates the pace of formation of social protection standards for servicemen of the Armed Forces of Ukraine. The article deals with the social protection of servicemen as a state activity in the field of social policy, which is aimed at ensuring a decent standard of living for servicemen and their families. The multilevel hierarchy of the system of social protection of servicemen of the Armed Forces of Ukraine is described. The role of ministries and other institutions that ensure the functioning of the social protection system of servicemen is examined. The types of pensions that are entitled to persons discharged from military service in our country are analyzed. The amount of pension benefits and other types of financial support is the basis for calculating pensions for servicemen in our country. The urgent task of implementing the pension reform is to avoid "equalization" of pensions for different groups of the population. In the case of accrual of pensions to servicemen, pensions are recalculated with some violations. Such violations include ignorance of certain components of financial support, such as payment for a scientific degree, payment for an academic title, and a number of allowances, including an allowance for sports titles, an allowance for honorary titles, and also an allowance for performing certain special functions within the scope of official powers. One step to increase the effectiveness of the social protection mechanism is to study, analyze and learn from the experience of similar procedures of foreign institutions. To identify ways of reforming the pension provision for servicemen in Ukraine, the article compares similar experiences in leading NATO member states such as the USA, Great Britain, and France. The choice of these countries is determined by the fact that the reform of the domestic pension system for servicemen in post-Soviet Ukraine is largely based on borrowing the experience of these countries. The conclusions of the article include recommendations for reforming the system of pension provision of Ukrainian servicemen.

Keywords: pension; retirement age; pension insurance; pension legislation; social protection. 